\title{
Earnings Management Practices From Perspective a Law and Ethical Views
}

\author{
Sri Arita ${ }^{1 *}$, Riyadi Aprayuda ${ }^{2}$, Defriko Gusma Putra ${ }^{3}$, Rita Syofyan ${ }^{4}$ \\ ${ }^{1,4}$ Universitas Negeri Padang, Padang, Indonesia \\ ${ }^{2}$ Universitas Muhammadiyah Riau, Pekanbaru, Indonesia \\ ${ }^{3}$ Universitas Andalas, Padang, Indonesia \\ *Corresponding author. Email: sriarita69@gmail.com
}

\begin{abstract}
The purpose of this study is to look at two different points of view of the practice of Earnings Management which is a management strategy to improve its financial statements, based on a legal point of view from the generally accepted rules of accounting and an ethical point of view. The two points of view differ because it is not certain that what is following the law will be following ethical principles. This research method uses a literature review related to the problems of companies that carry out earnings management, legal values, and moral ethics. The results of this study indicate that from a legal point of view, the practice of earning management which is often carried out in several companies is following generally accepted rules because this is a strategy used by management to manipulate company profits from its financial statements, while from the point of view of Moral Ethics, it is management's actions. not by ethics or unethical because it is misleading and is detrimental to various parties such as investors, the public, the government, and other users of financial statements.
\end{abstract}

Keywords: Earnings management, Legal rules, Ethics.

\section{INTRODUCTION}

In this era, especially in Indonesia, there have been many companies that have conducted initial public offerings (IPO) and have been listed on the Stock Exchange to improve performance and maximize owner welfare. According to Syofyan \& Putra [1], organizations or companies respond as living things or communities that aim to achieve the expectations of their creators. Listed companies on the stock exchange also aim to maintain the sustainability of their companies, such as sustainable existence, obtaining new sources of capital, business sustainability, and increasing the value and image of the company [2]. However, as a condition, companies must disclose their company's financial statements to the public as a reference for making decisions or public interests [3]. The company's revenue and net profit are one of the centers of attention of stakeholders in the company. Stakeholders' role models for better company performance are increasingly increasing [4]. Based on this, stakeholders can assess the performance or report cards obtained by the company in obtaining profits because, in reality, the company tends to look for profits [5]. Rasyid [6] explains that what becomes the center of attention of investors is income information using the capital maintenance concept presented in financial reports. Thus, every investor who reads the company's financial statements will pay attention to earnings. In addition, young investors will also take advantage of financial information, corporate governance, and sectoral information that affects the company [7-8]. Therefore, company management needs to strive for operating profit according to the expectations of stakeholders.

To attract investors 'attention, management is sometimes motivated to carry out strategies on how to increase its profits to attract investors' attention and beautify its financial statements for a given period. This is also encouraged so that their performance is seen to improve, and they will get cash compensation which is considered an implication of executive performance [9]. One of the shortcuts so that their company is judged to be working well and operating well which makes financial reports get the attention of investors and the public is to practice earnings management [10]. Taking a Bath, Income Minimization, Income Maximization, and Income Smoothing are types of earnings management practices in company financial reports [11]. In this case, management anticipates earnings in the financial statements to match the targets and needs of the company rather than presenting the actual profit results. Therefore, if the company's target is achieved, management does not need to use earnings management practices. However, if the earnings are 
not following the expected target, that is where the management motive arises to practice earnings management. The beginning of the emergence of a management motive to perform earnings management stems from certain management objectives to achieve the company's targets. However, sometimes this causes management to fall behind and ends up manipulating earnings in their financial reports. The earning management case will lead to fraudulent acts, such as those committed by Enron and Worldcom companies which harm many parties and make the accounting situation in a critical phase [12]. Another evidence is that the Paterson Company in the United States is proven to have carried out transfer pricing by intentionally increasing the price of the main raw material for its transfer to its subsidiary companies located in Europe to reduce profits to minimize taxes [13]. Based on this case, it can be said that earnings management actions are not only to attract investors' attention but also for certain interests such as tax avoidance.

Another case that has also appeared in Indonesia is the case of profit manipulation in financial reports by PT, Alfindo Putrasetia, Tbk (ADES) which provided misleading information to the public in the 2003 financial report, the misleading information was related to cases of differences in the calculation of production figures and sales figures in the report companies [14]. Then, PT. Kimia Farma, Tbk, where there is a misstatement related to inventory that arises because the value in the inventory price list has been inflated [15]. Furthermore, the same case also happened to PT. Indofarma Tbk, where there is evidence that the value of goods in the process is considered higher than the value that should be in presenting the value of goods in the process so that the presentation of inventory is too high, the cost of goods sold is too low and causes the net income presented to be overstated.

Based on the cases that have occurred, it can be said that the practice of earnings management will lead the company to take action towards financial report manipulation which causes the company to stumble in cases of fraud. However, even so, some earnings management activities are only given a warning by the authorized institution and are not given legal sanctions. Looking at the ethical-moral perspective of companies involved in fraud cases violates ethical principles because they have provided misleading information to users of that information. This is of course contrary to ethical principles because this action is detrimental to many parties, and an ethical perspective does not justify committing fraud, being honest, the value of integrity must take precedence over personal or organizational interests [16].

The incidence of earnings management practices that lead to corporate fraud can be avoided if the company promotes ethics of morality in its company. Management behavior that always applies ethical principles and humanitarian norms and always adheres to moral behavior will make management have ethical behavior that prevents the company from problems such as the cases that occur. In general, earnings management practices are not yet based on clear laws, this is an opportunity that at the same time motivates management to take this earnings management strategy even though it is concerned with the company itself and is likely to harm many parties.

The moral ethics of a manager will be tested, whether management puts forward the principles of applicable moral ethics and can control itself by not carrying out negative earnings management practices in any situation and condition, if the manager is classified as ethical management, he will always be consistent and stick to it. ethical principles carry out their activities. Thus, the management will avoid unethical actions, which makes the company prioritize an honest and trustworthy system, making the company's interests not only oriented towards personal interests but also concerned with many other parties because between the company and users of financial reports will need one another. each other. Companies must be prepared to experience the risk of financial difficulties or not generate much profit, management must be able to face risks as long as what management has done adheres to ethical moral values.

This study will try to describe the comparison of earnings management practices that often occur in companies from the point of view and point of view of moral ethics. Researchers argue that it is not necessarily what is by the law will be by the applicable ethical principles.

\subsection{Earnings Management}

Earnings management is defined as management's effort to intervene or manipulate information in financial reports to attract attention or fool stakeholders who want to know the company's performance and condition, earnings management is also an intervention with a specific purpose in financial reporting activities for the public or external parties. deliberately for personal gain [17]. Earnings management can also be interpreted as management's action to implement or select accounting policies from a certain standard to influence earnings that will occur as desired through factors that management does, namely internal factors that exist within the company [18]. Sugiri [17] argues that there are two earnings management, namely earnings management related to the choice of accounting methods, so here management interferes with the discretionary accrual component in determining the number of earnings and the second is management's action to increase or decrease reported earnings at the end of the period of this time for which a unit manager is responsible, without resulting in an increase or decrease in long-term economic profitability.

According to Scott \& O'Brien [18], there are four patterns implemented by management to carry out earnings management strategies, namely: 


\section{a. Taking a Bath}

This happens when a new CEO is appointed or has just served in a company, with a scheme of reporting large losses, the goal is to hopefully provide or increase profit period in the future. Management undertakes a strategy of shifting the expected future cost to the present, so those greater opportunities for future profits.

\section{b. Income Minimization}

This is done when the company experiences a high level of profit so that if it is predicted that in the coming period a drastic decline can be overcome by moving the profit from the previous period's profit. Management tries to take the burden of the past so that it has a greater chance of making a profit in the future.

c. Income Maximization

This is the opposite of income minimization, which occurs when profit decreases by moving the burden to the next period, the aim is to get high net income for bonus purposes or to increase the attractiveness of growing the image of the company to attract the attention of investors.

d. Income Smoothing

This is done by the company by leveling the company's net income to be reported so that too significant fluctuations in earnings will be reduced because the orientation of investors generally likes relatively stable profits.

\subsection{Motivation to do Earnings Management}

Luayyi [12] argues that based on agency theory, companies must give responsibility to managers for operating activities to create an operational success in carrying out their duties. However, if management fails to carry out its duties then the position and facilities owned by the manager will be at stake, the manager's reparation will be bad in the eyes of the owner besides that it will also affect the decline in the company's image in the eyes of the public because the company cannot operate properly, that is often the basis why managers want to do earnings management because they only want to protect themselves and cause losses in many parties.

Management as a manager must know a lot of information about the internal company and some predictions for the long term for the company, especially for compulsory publicity reports submitted to the stock exchange every year so that managers have to provide information on company condition reports however, in the case of information provided by the manager before it is given to the public, there must be many considerations made in advance if there are things that trigger a decline, increase, and profit discrepancies due to operating activities or other activities, that's where the manager's desire to implement management strategies arises. profit so that the information conveyed to the public, investors, owners of capital and other stakeholders is sometimes not by the actual conditions of the company. This condition is known as information asymmetry or information asymmetry occurs [21]. In this case, information asymmetry can provide opportunities for management to carry out earnings management.

Especially for companies that are listed on the stock exchange, there is motivation to make the company considered good by investors, one way is by generating high income because if many investors invest their funds in the company, it will increase the company's funds to generate stable profits. investors will be interested in investing in the company. Also, some companies involve leverage as a source of funding capital because it can improve and help management performance for the continuity of the company's operations, if performance increases, investors will be more interested in paying higher share prices to the company [22]. This also greatly motivates management in carrying out company management activities using negative earnings management practices, because the orientation is only on achieving maximum profits so that they do not think about long-term impacts and from an existing ethical perspective. Another motivation for doing earnings management is for tax savings, where management tries to minimize profits to reduce the tax burden to be paid because the higher the value of profit, the higher the amount of tax burden to be paid.

\subsection{The case of companies that carry out earnings management}

\section{Peterson Company}

The Paterson company is a US-based company that manufactures and sells electronic components worldwide. This company has a subsidiary in Europe, which is located in France that does transfer pricing, the parent company that supplies raw materials for the main product in America suddenly increases the price from $\$ 5.00$ to $\$ 5.50$ which should have been agreed between the divisions that the per-unit price is $\$$ 5.00 during the current year. Here the subsidiary complains that if the price is maintained, it will be detrimental to its foreign exchange which is at least \$ 600 with the increase in prices at the beginning of the year, it turns out that the aim of the price increase is driven by the reason that conditions in the US are not as good as in Europe in terms of profitability. So with an increase in prices for the main products transferred to Europe to its foreign exchange, income and profits in the United States will increase, so it can transfer the increase in income, resulting in two ways at once, including reducing the amount of taxes paid by Europe to be precise in France. and also the losses that occur in America can secure the number of tax payments to increase net cash flow [13].

\section{PT. Ades Alfindo Putra Setia, Tbk}

The Capital Market Supervisory Agency (Bapepam) ensures that the management of PT. Ades Alfindo Putrasetia Tbk (ADES) has provided 
misleading information to the public. The information misleading is related to the difference in the calculation of production figures and sales figures in the company's financial statements. The ADES new management report regarding the existence of information inflating by the old management was not accompanied by sufficient evidence, ADES management reported that there had been discrepancies regarding the potential for differences in financial statements from 2001 to 2003. Estimated calculations regarding the potential differences in production volume with volume What the company reports to the trademark owner on the production volume with the volume that the company reports to the trademark owner on the sales is for 2001 the difference in volume against net sales is estimated at a maximum of $\mathrm{Rp} 13$ billion. For 2002 it was IDR 45 billion, for 2003 it was IDR 55 billion and IDR 2 billion for the middle of 2004. These estimates could represent a maximum difference of 10 percent, 30 percent, 32 percent, and 3 percent lower than the reported sales in the years mentioned above [14].

\section{PT. Kimia Farma, Tbk}

The Capital Market Supervisory Agency (Bapepam) confirmed that PT. Kimia Farma, Tbk, the value of goods in the process is considered to be higher than the value it should be (overstated) in the presentation of the value of goods in process in the 2001 financial year amounting to Rp. As a result, the cost of goods sold has been understated and net income is overstated by the same value. As is well known, Kimia Farma is strongly suspected of marking up its net income in its 2001 financial statements. In the report, Kimia Farma said that it managed to make a profit of Rp 132 billion. In 2001, the pharmaceutical company only made a profit of Rp. 99 billion [15].

\subsection{Earnings Management Based on Empirical Evidence}

In research Susilawati [23], from her research, analysis of earnings management at the time of the IPO was carried out in 30 companies that conducted Initial Public Offering 2004-2005. The results obtained from all 30 companies support that discretionary accruals are opportunities for management to manipulate accounting earnings or income, in which the concept of management can manipulate accrual income to achieve the desired income. So the discretionary accruals are proven to have been carried out by the company at the time of the offering at the time of its first share withdrawal during the IPO. Because it is predicted that the company's performance will decline.

Runturambi et al. [24] conducted a study analyzing companies that carried out earnings management in the Food and Beverages industry in 2015-2016 using the Healy model, Angelo Model, Jones Model, and Modified Jones Model methods. The analysis was carried out in 15 Food and Beverages companies.
They found evidence was detected that 15 companies carried out earnings management by reducing company profits. In particular, in 2016 there were 5 companies detected practicing earnings management by increasing company profits, and

10 others practicing earnings management by reducing their profits. Based on the overall results of [24] companies that are the object to be researched carry out earnings management, either decreasing or increasing their percentage level of profit.

\section{METHODS}

This research was conducted by applying a qualitative descriptive method. According to Sofyan et al. [22] explain that qualitative descriptive research aims to understand and analyze phenomena that occur in the business world with facts obtained in the field which are used as material for analysis related to problems that arise to obtain answers or solutions to these problems. This research will later be more directed at describing a phenomenon of earnings management that occurs in companies and based on the applicable ethical concept, which aims to describe these two points of view to obtain a deeper understanding and information regarding this matter. The literature review used in this study is used by searching for previous literature related to the theme to be presented, which is then collaborated with the author's thoughts to find a form of conceptual understanding that can provide information for the wider community in general and the author in particular about the themes discussed.

\section{RESULTS AND DISCUSSION}

\subsection{Is Earnings Management Including Fraud from a legal perspective?}

According to Runturambi et al. [24] earnings management is the center of attention in accounting because the role of earnings is very large and very important in financial reports, there are still many pros and cons because the old management is still abstract on all sides, starting from the technique or conceptually, conceptual debates. It can be seen from the basic thing, the fact that the profit figures are technically the result of manipulation because the profit figures use the accrual concept approach, determined by the accountants themselves. This is very different from the concept of market value if in ideal conditions it is objective, for example, the market value of a public company or issuer in the capital market is something that cannot be tampered with.

In study Kurniawansyah [26], it discusses whether earnings management is an act of fraud that violates the law, in his research discusses earnings management is based on the accrual principle, accrual is the difference between earnings and cash flow. Because most accounting activities involve the accrual system, for example, credit sales to companies will create accruals 
because sales are recognized when the transaction is made. Therefore, earnings management can be considered as a strategy for transferring temporary income from period to period.

However, if the company has a principle of an aggressive approach to the determination of its accounting policies, then the company usually borrows income in the coming period, and if the company uses a conservative approach, the current income will be saved first to encourage income that occurs in the coming period. This is the nature of the accrual system.

Fraud of a financial nature can be defined by the national association of certified fraud examiners as intentional, planned misrepresentation, or hiding material facts in accounting data that causes errors so that users of financial statements change their decisions. Profit management itself is a legal tip of action, earnings management can lead to fraudulent acts if it is likened to a boundary bridge, then financial fraud is the end of the blockage.

Earnings management is not fraud, fraud is an act of fraud that violates the law, which is criminal in nature or fraudulent behavior that can be criminalized [27]. Fraud is a condition that is against the law or does not have legitimacy, while earnings management is at the legal limit, the deviation from the profit reported by the company from operating results or economic profit is considered legitimate earnings management and according to accounting and company law standards, For example, tax avoidance, which is allowed, but has been criticized by many parties. Thus, it is not justified to judge earnings management as fraudulent because the results and orientation are different. As the result, earnings management and earnings fraud indeed lead to dishonest disclosures, while earnings management itself is based on generally accepted accounting standards in the company [26]. Anything that violates the law is only limited if these activities are carried out: 1. Reporting of Fictional Sales. 2. Report the sale of products that have not been shipped. 3. Not sufficiently recorded all expenses and expenses. 4. Conduct barter transactions for goods or services with an overvalued or undervalued system. 5. Higher asset valuation 6. Capitalizing costs inaccurately [26]. Apart from that, earnings manipulation is considered a management strategy for the company's operations because it is considered to be by generally accepted accounting standards. After all, it is considered that earnings management tends to be allowed, so for the whole earnings management tends to be a strategy or management's effort in selecting methods. the usual accounting policy for presenting profit in the company profile because it is permissible according to accounting standards. Management can choose many ways to influence the time and amount that affect the numbers of a profit-oriented transaction by making accounting choices and accounting judgments.

\subsection{Profit Management from a Moral Ethical Point of View}

Dishonesty is often clearly illustrated in the practice of earnings management where management interferes rather than showing real results for the good of the company, from the point of view of moral ethics something ethical must be based on such as being honest, cooperating with others, and most importantly is that moral ethics has the characteristic of prioritizing the interests of others or common interests over personal interests, moral ethics is adhered to because awareness is not because it involves rewards and benefits but by one's awareness, morals do not have to be written by a rule but exist in every value and civilization of society [28].

Earnings management is very self-interested because it is embedded there to create a company image and want to attract the attention of users of financial statements such as investors, if profits are large, the company is considered to be profitable in terms of generating profits, therefore management tends to strategize how profits are greater than displaying the real condition of profit is unethical because it will mislead investors' decisions because they have invested in a company where the company cannot get the profit it should. As an example of a case carried out by a company that wants to conduct an IPO in the capital market from research before the Initial Public Offering, the company deliberately manipulates its income even though it is accrual, but still, it is unethical because it deviates from honest behavior and can harm investors who invest during the company's initial trading. It is possible that if investors do not sell their shares after the IPO, it might be detrimental to these investors because from the results of research on the company's performance afterward, it will decline, and the selling price of shares will automatically decrease.

Compliance with legal norms is not always ethical. Law and ethics are not always equal. Often a distinction is made between professional ethics and moral ethics. In reality, there shouldn't be any difference. Professional ethics must be driven by what is fundamentally right or wrong. Ethical behavior is choosing the "right" and "right" and "fair" actions. Behavior can be right or wrong, it can be right or not, and the decisions we make can be fair or unfair. Although there are competing ethical systems, each of which tries to define what is right or wrong, there is a general principle underlying all ethical systems. This general principle, which is at the heart of ethical action, is the willingness to sacrifice one's interests for the welfare of others. This ethical principle does not hinder the pursuit of profit by an organization. In planning, controlling, and decision-making, however, managers must always consider the impact of their actions on others, both within the organization and without. Thus, the objective of profit maximization must be limited by the requirement that profits be attained by ethical means. 


\section{CONCLUSIONS}

Between moral ethics and law is a difficult thing to reconcile. Earnings management is more associated with compliance with the law, whereas moral ethics is rarely considered by someone in making decisions. What is true in the practice of earnings management according to the law, is not necessarily right ethically. This happens because earnings management is more based on the legal aspects of accrual-based accounting standards so that it is considered only a management strategy. Thus, even though the company does not violate the law, but morally by carrying out earnings management the company is responsible for the absence of such economic substance. Profit management is not something that counts as fraud or violates the law but it is on the line that leads the company to the brink of committing illegal acts because it is in the line of legal boundaries from a legal point of view, but from an ethical perspective it has violated due to non-conformity. Earnings management is familiar with something that is dishonest and tends to be detrimental to many parties because the information presented is not by the actual conditions of the company.

\section{REFERENCES}

[1] R. Syofyan and D. G. Putra, "The Role of Good Corporate Governance (GCG) Implementation in Indonesian Company," vol. 124, pp. 819-825, 2020, doi: 10.2991/aebmr.k.200305.148.

[2] T. Hasan, M. Hadad, and K. Ahmed, "The accuracy of management profit forecasts in IPO prospectuses Evidence from Indonesia," $J$. Account. Emerg. Econ., vol. 6, no. 1, pp. 2-12, 2016.

[3] O. Sinaga, "Analisis Kinerja Keuangan Perusahaan Bankkaltimtara Sebagai Syarat Pengajuan Initial Public Offering (Ipo) Di Bursa Efek Indonesia," Madani Account. Manag. J., vol. 6, no. 2, pp. 99-119, 2020.

[4] D. G. Putra and R. Rahayu, "Peranan Implementasi Tata Kelola Teknologi Informasi (IT Governance) sebagai Faktor Penting dalam Meningkatkan Kinerja Perusahaan," J. Inov. Pendidik. Ekon., vol. 10, no. 1, pp. 01-07, 2020.

[5] D. R. Wahyuningsih, "Hubungan Praktik Manajemen Laba dengan Reaksi Pasar atas Pengumuman Informasi Laba Perusahaan Manufaktur di BEJ," Diponegoro J., pp. 1-72, 2007.

[6] E. Rasyid, Pelaporan keuangan Semenjak Akhir 1800an sebelum the Great depression ke awal 2000an setelah krisis global Ekonomi : Refleksi integritas akuntan. Padang: Universitas Andalas, 2010.

[7] R. Aprayuda and F. Misra, "Faktor Yang Mempengaruhi Keinginan Investasi Investor Muda di Pasar Modal Indonesia," E-Jurnal Akunt., May 2020, doi: 10.24843/eja.2020.v30.i05.p02.

[8] R. Aprayuda, F. Misra, and R. Kartika, "Does Order of Information Affect Investors' Investment Decisions?: Experimental Investigation," J. Account. Invest., vol. 22, no. 1, 2021, doi: https://doi.org/10.18196/jai.v22i1.9965.

[9] T. Husni, R. Rahim, and R. Aprayuda, "Cash Compensation, Corporate Governance, Ownership, and Dividend Policy on Banking Performance," 2020, doi: 10.2991/aebmr.k.200331.046.

[10] D. Priantinah, "Manajemen Laba Ditinjau Dari Sudut Pandang Oportunistik Dan Efisien Dalam Positive Accounting Theory," J. Pendidik. Akunt. Indones., vol. VII, no. 1, pp. 99-109, 2009.

[11] I. Kamil, "KONSEP PRAKTIK MANAJEMEN LABA DALAM PERSEPSI ETIS

MAHASISWA (Studi Kasus Pada Universitas XYZ)," J. Profita, vol. 11, no. 1, p. 053, 2018, doi: 10.22441/profita.v11.01.004.

[12] S. Luayyi, "Teori Keagenan Dan Manajemen Laba Dari Sudut Pandang Etika Manajer," El Muhasaba J. Akunt., vol. 1, no. 2, pp. 199-216, 2012, doi: 10.18860/em.v1i2.1871.

[13] D. R. Hansen, R. L. Crosser, and D. Laufer, "Ethics v . Tax Ethics : The Case of Transfer Multinational Pncing Among Doug Laufer Rkk L Cwsser Corporations," J. Bus. Ethics, vol. 11, no. 9, pp. 679-686, 1992.

[14] Finance Detik, "Manajemen Baru ADES Berikan Informasi Salah," 2004.

[15] Tempo, "Bapepam: Kasus Kimia Farma Merupakan Tindakan Pidana,” 2004.

[16] L. J. Brooks and P. Dunn, Etika Bisnis dan Profesi untuk Direktur dan Eksekutif, dan Akuntan (Edisi 5 Buku 2). Jakarta: Salemba Empat, 2015.

[17] K. Schipper, Earnings management Accounting Horizons. 1989.

[18] E. S. S. Alzoubi, "International Journal of Accounting \& Information Management For Authors Ownership structure and earnings management: evidence from Jordan," Int. J. Account. Inf. Manag., vol. 24, no. 2, pp. 1-20, 2016.

[19] S. Sugiri, "Earnings management: Teori, model, dan bukti empiris," J. Akunt., pp. 1-18, 1998.

[20] W. Scott and P. O'Brien, Financial accounting theory (Vol. 3). Toronto: Prentice- Hall, 2003.

[21] H. Wibisono, "Pengaruh Manajemen Laba terhadap Kinerja Perusahaan di Seputar Seasoned Equity Offerings (Studi Empiris di Bursa Efek Indonesia).” pp. 1-101, 2004.

[22] S. Utama, "Teori dan Riset Akuntansi Positif: Suatu Tinjauan Literatur," J. Ekon. dan Bisnis Indones., 2000.

[23] R. A. E. Susilawati, "Jurnal Infestasi," J. Infestasi, vol. 3, no. 2, pp. 87-101, 2006.

[24] I. V Runturambi, W. Pontoh, and N. T. 
Gerungai, “Analisis Manajemen Laba pada Perusahaan di Sektor Industri Food and Beverage yang terdaftar di BEI Tahun 2015-2016," Fak. Ekon. dan Bisnis, Jur. Akuntansi, Univ. Sam Ratulangi, vol. 12, no. 2, pp. 857-873, 2017.

[25] R. Sofyan, D. G. Putra, and R. Aprayuda, "Does the Information onSofyan, R., Putra, D. G., \& Aprayuda, R. (2020). Does the Information on the Internet Media Respond to the Stock Market? Proceedings of the 5th Padang International Conference On Economics Education,

Economics, Business and Manageme," Proc. 5th Padang Int. Conf. Econ. Educ. Econ. Bus. Manag. Account. Entrep. (PICEEBA-5 2020), vol. 152 , pp. 510-520, 2020, doi: 10.2991/aebmr.k.201126.057.

[26] D. Kurniawansyah, "Apakah Manajemen Laba Termasuk Kecurangan ? : Analisis Literatur," $J$. Ris. Akunt. Dan Bisnis Airlangga, vol. 3, no. 1, pp. 341-356, 2018, doi: 10.31093/jraba.v3i1.97.

[27] N. Yaping, "A Different Perspective of Earnings Management," Can. Soc. Sci., vol. 2, no. 4, pp. 53-59, 2006.

[28] Gustina, "Etika Bisnis Suatu Kajian Nilai Dan Moral Dalam Bisnis," POLI BISNIS, vol. 3, no. 2, pp. 137-146, 2012. 